\title{
Impacts of Land Cover Dynamics and Shallow Groundwater Abstraction on Sustainability of Hakwatuna Oya Irrigation System
}

\author{
I.P.S.K. Pelpitiya ${ }^{*}$, N.D.K. Dayawansa ${ }^{1}$ and E.R.N. Gunawardena ${ }^{1}$ \\ Postgraduate Institute of Agriculture \\ University of Peradeniya \\ Sri Lanka
}

\begin{abstract}
Deforestation, expansion of agriculture and over abstraction of groundwater in watersheds can influence the water yield. Hakwatuna Oya watershed area in Deduru Oya basin also faces a similar situation due to rapid land use/cover changes and associated impacts. This study was conducted to identify the land use change dynamics and their possible impacts on the inflow to the Hakwatuna Oya reservoir. Land use mapping was done using 1:50,000 topographic maps and Landsat TM, ETM+ and OLI satellite images of 1994, 2003 and 2014 and the changes were assessed using GIS. Measured pump discharges rates and duration of pumping was used to calculate the total groundwater abstraction per month based on the average hours of irrigation and the duration of cultivation. Secondary data on rainfall, evaporation, reservoir storage and water issues were used to calculate the inflow using a water balance study. Assessment identified that forest, home gardens and agricultural area changes are the most prominent during 1986 to 2014. Proliferation of agro-well irrigation was observed as a result of agricultural activities with an agro-well diffusion of $71 / 100$ farmers and agro-well density of $110 / \mathrm{km}^{2}$ of agricultural land area; exceeding the recommended value of $100 / \mathrm{km}^{2}$. No statistically significant change was observed in reservoir inflow with time. Although the temporal changes of reservoir inflow was not statistically significant, even a slight reduction of inflow can have a considerable impact to the farmers due to sensitivity of water availability for agriculture. Therefore, it is important to manage the watershed area of Hakwatuna Oya to preserve the ecosystems and to maintain the water yield for the sustainability of the downstream irrigation system.
\end{abstract}

Keywords: Abstraction, groundwater, inflow, land use/cover, watershed

\section{INTRODUCTION}

Reservoirs are mostly built in dry areas for storing water to prevent wastage and increase availability during non rainy periods. They are mainly used to support agricutural production by providing irrigation water (Abeysinghe et al., 2005; Biemans, et al., 2011). River runoff and direct rainfall occur during rainy season are the main sources of water stored in these surface reservoirs to be used during dry season (Güntner et al.,

\footnotetext{
1 Department of Agricultural Engineering, Faculty of Agriculture, University of Peradeniya, Peradeniya, Sri Lanka.

* Corresponding author: sandamrt@gmail.com
} 
2004). Additionally, some of these reservoirs are built for hydropower generation, to reduce discharge variability, for improved navigation and other users (World Commission on Dams, 2000; International Commission on Large Dams, 2007). Over the time, it has been recognized that drastic climatic changes and human activities pave way for great impacts on the hydrological processes and water resources in upper river basins (Wang et al., 2012). Climate change contributes to reduce the inflow to surface reservoirs, and simultaneously increases the requirement for irrigation water in the downstream (Van Oel et al., 2008).

Increase of population, economic and social development can seriously affect on the watershed land use and the hydrological cycle (Wang et al., 2012). These land cover changes directly influence evapotranspiration, infiltration, and soil water storage, dynamics of surface and subsurface runoff, groundwater recharge and also inflow to the agricultural reservoirs located in watershed outlets (Park et al., 2009). Moreover, upstream abstraction for irrigation purposes is another major cause for low flows in rivers (Smakhtin, 2001; Smakhtin et al., 2006; in Van Oel et al., 2008). Therefore, monitoring land use/ cover dynamics and assessing impacts of land use/cover changes on hydrology is an important aspect (Nie et al., 2011) to maintain good inflow to the downstream reservoirs.

Gaiser et al. (2003) mentioned the importance of recognizing the scarcity of water resources in semiarid regions due to large variability of climate and the increasing water demand as a result of changing climatic, environmental and socioeconomic conditions. Adaptation of integrated measures of water management is required to secure water availability from reservoirs in the future (Güntner et al., 2004). Analysis of hydrological data provides significant statistical information for both past and future characteristics of a basin. Especially, recording and modeling of reservoir inflow data have considerable roles in reservoir operation studies and water resources planning (Okkan, 2012). Hakwatuna Oya reservoir is located in the North Western province of Sri Lanka and feeds a major irrigation system. A field survey and a past study (Samaranayake, 2011) revealed that a considerable change in land use/cover has occurred in the watershed area due to increasing human settlements and land clearing for agriculture during the past three decades. Shallow groundwater abstraction using agro wells to irrigate upland crops is a common phenomenon in this watershed. Water availability in the reservoir is vital to the sustainability of the irrigation system. This study attempted to identify the changes in land use/cover in the watershed area and their possible impacts on inflow to the Hakwatuna Oya reservoir which feeds a major irrigation system.

\section{MATERIALS AND METHODS}

\section{Characteristics of the study area}

Hakwatuna Oya watershed is located in Deduru Oya basin and consists of an extent of $64 \mathrm{~km}^{2}$. It feeds the Hakwatuna Oya reservoir to cultivate irrigable area of 2578 ha (Department of Irrigation, Kurunegala, 1999). Approximately, 2662 farmers and 2053 farmer families live in the watershed area (Rambe and Madahapola Agrarian Service Centers, 2013). The area belongs to $\mathrm{IL}_{3}, \mathrm{DL}_{1 \mathrm{~b}}$, and $\mathrm{IM}_{3 \mathrm{~b}}$ agro ecological regions and it receives greater than $1100 \mathrm{~mm}$ of annual rainfall (Punyawardana, 2008). A total of 17 
minor tanks and a number of anicuts are present in the watershed area. Irudeni Ela, Kosgaha Ela, Gomadiya Ela and the Hakwatuna Oya are the main streams feeding Hakwatuna Oya reservoir. This reservoir has been rehabilitated in 1957 and supplies water to the Hakwatuna Oya irrigation scheme that was established in 1964. Fig.1 shows the location of Hakwatuna Oya watershed and Hakwatuna Oya reservoir.

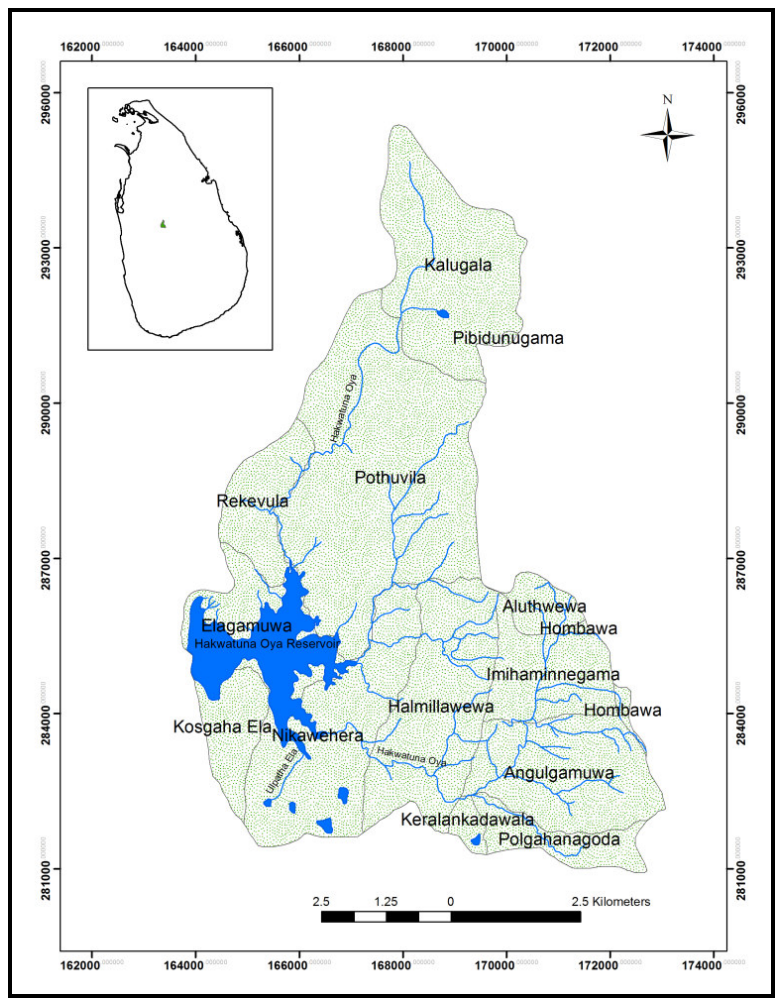

Fig.1. Location of Hakwatuna Oya watershed and Hakwatuna Oya reservoir

\section{Methodology}

Dynamics in the land use/land cover in the study area was assessed based on existing maps and satellite images. In this respect, 1:50,000 scale topographic map of Dambulla, Sri Lanka in 1986, Landsat TM image acquired on $11^{\text {th }}$ September 1994, Landsat ETM+ image acquired on $31^{\text {st }}$ January 2003 and OLI/TIRS image acquired on $06^{\text {th }}$ February 2014 (obtained from United States Geological Survey -USGS website) and IKONOS images acquired on $03^{\text {rd }}$ January 2014 (Obtained from Google Earth) were used. IKONOS data were primarily used as a substitute to ground truth due to high spatial resolution. Manual digitizing was carried out to demarcate the land use/ cover boundaries using ArcGIS 10.2 software. This multi temporal data set was used to identify the extent of different land use/ cover during each time and to assess the changes over the time period. 
The average pump discharge rates were measured from the selected 218 agro wells situated in Hakwatuna Oya watershed. Pump discharge rates and duration of pumping was used to calculate the total groundwater abstraction by the farmers per month based on the average hours of irrigation per month and the length of cultivation season. Hakwatuna Oya monthly rainfall data and Batalagoda pan evaporation data from 1987 to 1993 and 2005 to 2010 were used to calculate rainfall yield and total evaporation by the reservoir surface respectively. Deep percolation was calculated as $0.05 \%$ of reservoir storage (Wijesekera et al., 2001). There are no records on reservoir inflow. Hence, secondary data on reservoir capacity and water issues from 1987- 1993 and 2005 to 2010 were used to calculate the inflow to the reservoir from the watershed area using a water balance equation (Equation 1). The reason to identify the above two time series is that it was not possible to obtain a complete set of data for the other time periods. Fig. 2 shows the schematic diagram of reservoir water balance.

$$
\Delta \mathrm{S}=(\mathrm{IF}+\mathrm{RFY})-(\mathbf{I}+\mathbf{E}+\mathbf{D}) \ldots \ldots \ldots \ldots \ldots \ldots \ldots(\text { Equation } 1)
$$

Where;

IF

RFY

I

$\mathrm{E}$

$\mathrm{D}$

$\Delta \mathrm{S}$
- Inflow $\left(\mathrm{m}^{3}\right)$

- Rainfall Yield to reservoir $\left(\mathrm{m}^{3}\right)$

- Water Issues $\left(\mathrm{m}^{3}\right)$

- Evaporation from reservoir $\left(\mathrm{m}^{3}\right)$

- Deep percolations and seepage losses $\left(\mathrm{m}^{3}\right)$

- Change of reservoir storage $\left(\mathrm{m}^{3}\right)$

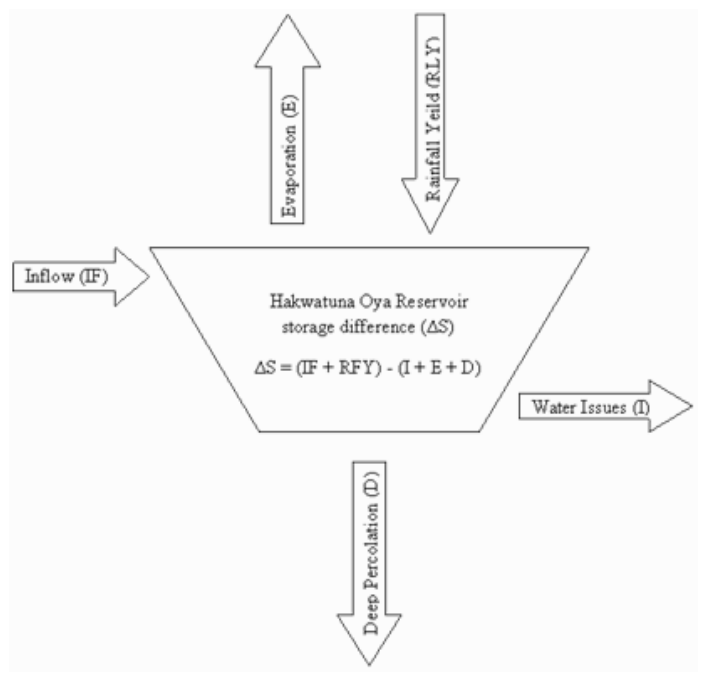

Fig. 2. The schematic diagram showing reservoir water balance

Average minimum, maximum and total annual inflow values were calculated to find out the variation of inflow with time. The two sample $\mathrm{T}$ test was used to identify any significant change in the monthly reservoir inflows during the two time periods. Temporal variation of reservoir inflow with rainfall was also assessed and runoff 
coefficient was calculated for the two time periods to identify any difference. A comparison of reservoir inflow with groundwater abstraction in watershed area were carried out using correlation analysis and regression analysis to identify whether there is an influence of groundwater abstraction to change the reservoir inflow with time. Further, the possible impacts on monthly reservoir inflow due to monthly groundwater abstraction over the time in upper watershed area were also assessed.

\section{RESULTS AND DISCUSSION}

\section{Land use/cover dynamics in Hakwatuna Oya watershed area}

Hakwatuna Oya watershed has been subjected to changes since the period of reservoir rehabilitation in 1960s (Samaranayake, 2011). These changes may have possible influences on multiple aspects including watershed hydrology; changing inflow to the reservoir, food security, human-elephant conflict and water availability for cultivation in the irrigation scheme. Fig. 3, 4, 5 and 6 present the land use/land cover of Hakwatuna Oya watershed in 1986, 1994, 2003 and 2014, respectively. From the satellite images, nine different types of land use/cover were identified namely; coconut, forest, grassland, home garden and agriculture, home garden and other plantations, paddy, scrub and primary forest, rock and water (Reservoir). Forest cover is mostly confined to the northern part of the watershed and shrinking of forest cover is visible with time. Home gardens, plantations and agricultural lands are scattered in other places of the watershed. Hakwatuna Oya reservoir is the prominent water body in the area other than few small tanks.

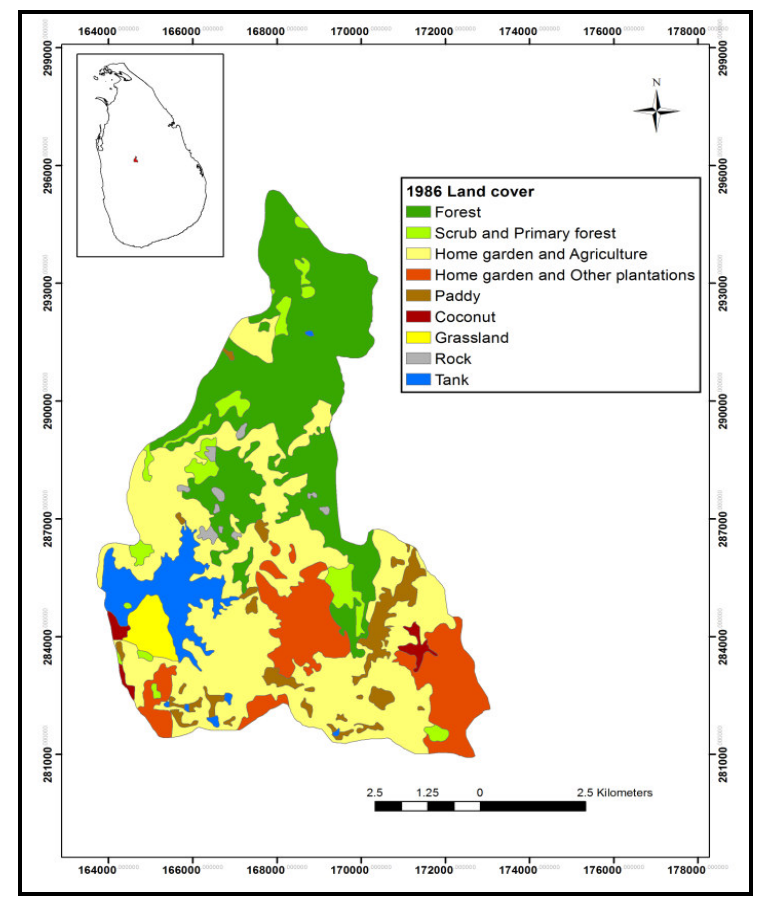

Fig. 3. Land use/ cover of the Hakwatuna Oya watershed in 1986 
Pelpitiya et al.

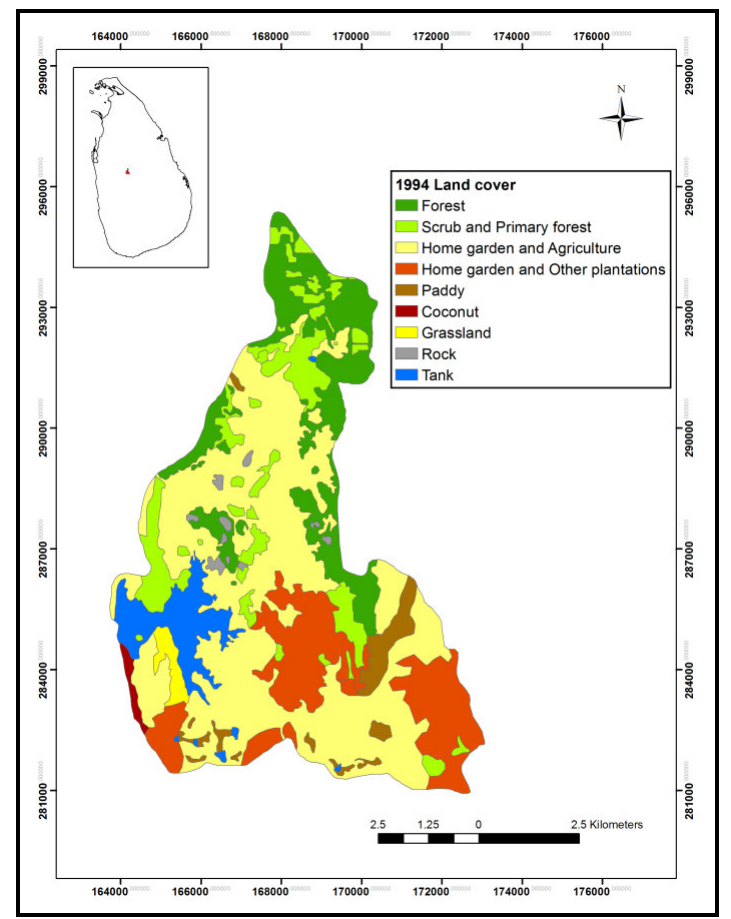

Fig. 4. Land use/ cover of the Hakwatuna Oya watershed in 1994

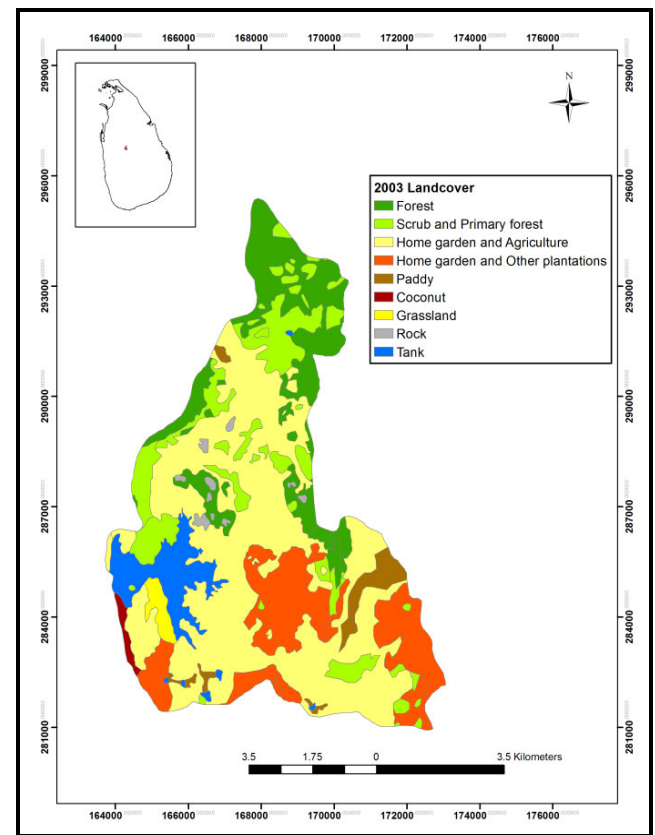

Fig. 5. Land use/ cover of the Hakwatuna Oya watershed in 2003 


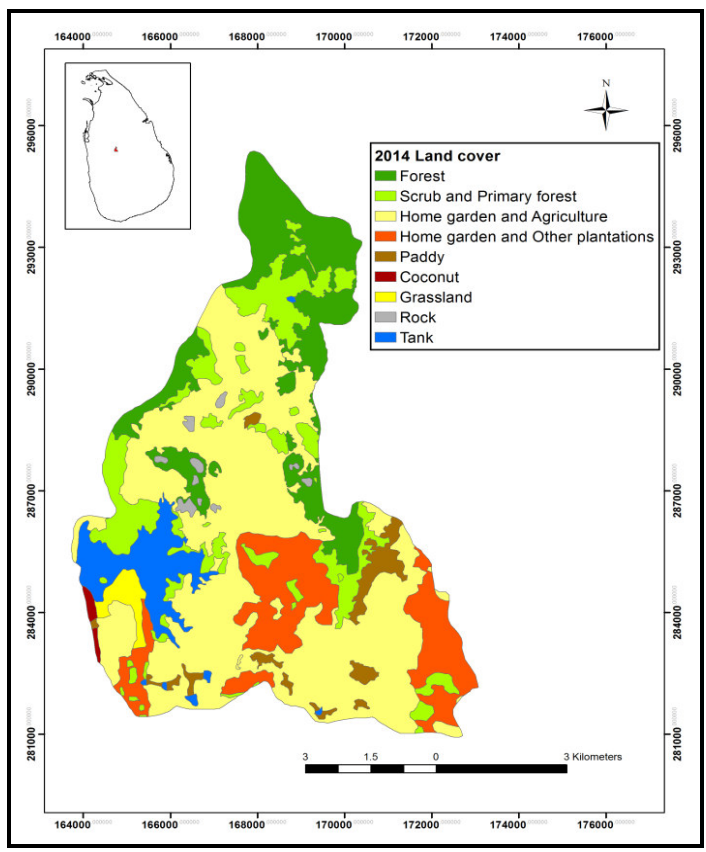

\section{Fig. 6. Land use/ cover of the Hakwatuna Oya watershed in 2014}

Table 1 shows the land cover changes as a percentage of total watershed over the period of 1986-2014. According to the derived statistics, a reduction in forest cover was identified during 1986 to 1994 period. During the same period, expansion of home garden and agriculture is clearly visible. These changes have continued up to 2014 though there are slight deviations from 1994 to 2014. It was distinguished that most of the changes have taken place in forest, home garden and agriculture and scrub and primary forest land cover. These changes have happened as a consequence of clearing the forest cover for the expansion of agricultural activates and village settlements.

Table 1. Land cover changes as a percentage of total watershed over the period of 1986-2014

\begin{tabular}{lcccc}
\hline \multirow{2}{*}{ Land cover } & \multicolumn{4}{c}{ Land cover change as a percentage of total } \\
& \multicolumn{4}{c}{ watershed area } \\
\cline { 2 - 5 } & $\mathbf{1 9 8 6}$ & $\mathbf{1 9 9 4}$ & $\mathbf{2 0 0 3}$ & $\mathbf{2 0 1 4}$ \\
\hline Coconut & 0.92 & 0.55 & 0.55 & 0.35 \\
Forest & 30.02 & 15.17 & 15.18 & 16.49 \\
Grassland & 1.90 & 1.17 & 1.13 & 1.33 \\
Home garden and Agriculture & 39.13 & 46.29 & 45.16 & 45.84 \\
Home garden and Other plantations & 12.85 & 15.77 & 15.51 & 13.01 \\
Paddy & 4.37 & 3.26 & 2.55 & 2.95 \\
Rock & 0.75 & 0.75 & 0.75 & 0.75 \\
Scrub and Primary forest & 4.17 & 11.14 & 13.27 & 13.39 \\
Tank & 5.89 & 5.89 & 5.89 & 5.89 \\
\hline
\end{tabular}


The forest cover of the area in 1986 (30.02\%) has reduced in to half in $1994(15.17 \%)$ indicating a considerable impact on forest cover of the watershed. Even though there is a slight increase of forest cover in $2003(15.18 \%)$ and $2014(16.49 \%)$ as shown in the analysis, this may be due to limitations in the satellite image interpretation. During the same time period, home garden and agriculture extents have increased by $39.13 \%$ (1986) to $46.29 \%$ (1994). These extents have become more or less constant during 2003 $(45.16 \%)$ to $2014(45.84 \%)$ period. There is a reduction in coconut cultivation with time. During the field survey, farmers revealed that wild elephants destroy their coconut cultivations hence some of them have abandoned cultivating coconut. Some farmers are engaged in farming near to the reservoir using pumped water from the reservoir during water scarce periods. Therefore, the area covered by grassland near to the reservoir is changing with this seasonal cultivation practices.

There is an increment in the extent of home garden and other plantations from 1986 to 1994 which can be a result of emergence of village settlements. However, a reduction can be seen during 1994 to 2014 and some of them have converted to home garden and agriculture. Some of these lands have been converted to scrub and primary forest due to abandoning of agricultural activities. Paddy land extent also shows a variation from time to time. Survey discussions revealed that some farmers abandon paddy cultivation and move to the Other Field Crops (OFCs) due to inadequacy of water for paddy cultivation. Farmers tend to abandon agricultural lands due to low returns resulted from poor market prices, high production cost, water scarcity and elephant damages as revealed in the field survey. Hence, conversion of agricultural lands to scrub and forest is visible in the area during 1986 to 2014.

\section{Shallow groundwater usage through agro-wells}

According to the statistics collected in the field, the collected information regarding the agro-wells is given in Table 2.

Table 2. The general details of agro-wells and shallow groundwater abstraction

\begin{tabular}{lc}
\hline Parameter & Description/ statistics \\
\hline Average depth $(\mathrm{m})$ & 7.2 \\
Average water level (m) & 3.8 \\
Average diameter (m) (change with season) & 4.5 \\
Rate of diffusion of agro-wells (number of agro-wells per & 71 \\
100 farmers) & \\
Density of agro-wells per $1 \mathrm{~km}^{2}$ & 110 \\
Estimated total number of agro-wells for 2662 farmers & 1890 \\
Methods of constructing agro-wells & Hand or mechanical digging \\
Water abstraction method & Water Pumps \\
Average pumping capacity (m 3 / hour) & 6.0 \\
Average pumping duration (hours/day) & 2.8 \\
\hline
\end{tabular}

Field survey revealed, $79 \%$ of the farmers use agro-wells as their main water source for upland cultivation. According to the survey, the agro-well construction has started before 1983 but majority of the wells have been constructed during 1984-2013 period. Highest percentage of agro wells (45\%) in the area has been constructed during 1994-2003 
period (Fig. 7). The survey revealed that $68 \%$ of the farmers in the area have settled and started agricultural practices in the area before 20 years. It is evident that diffusion of agro-wells has started to increase with the settlement of the people.

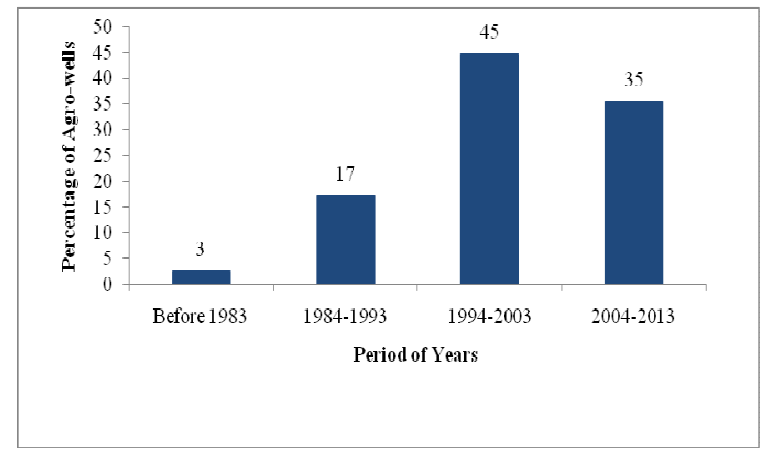

Fig. 7. The increment of agro-well construction over the decades as a percentage

According to the information, the highest density of agro-wells was found from Imihaminnegama Grama Niladhari (GN) division (180 wells $/ \mathrm{km}^{2}$ ) and the lowest density was found in Kosgaha Ela GN division. Field survey revealed that low density of agro-well in Kosgaha Ela $\left(25\right.$ wells $/ \mathrm{km}^{2}$ ) is due to perennial crop cultivation compared to OFC. Relatively high density of agro wells in all other GN divisions is an indication of the practicing of intensive commercial agricultural activities.

\section{Reservoir inflow variation from 1987-1993 and 2005-2010 periods}

Fig. 8 shows the variation of total annual inflow to the reservoir from 1987-1993 and 2005-2010. The solid line shows the average annual inflow during the two time periods compared with the total annual inflows in respective years. According to the assessment, the average annual inflow (23.36 million $\mathrm{m}^{3}$ ) for 1987 to 1993 period is higher than the average annual inflow (22.02 million $\mathrm{m}^{3}$ ) for 2003 to 2013 period. Lowest annual inflow to the reservoir during both time periods was report in 2009.

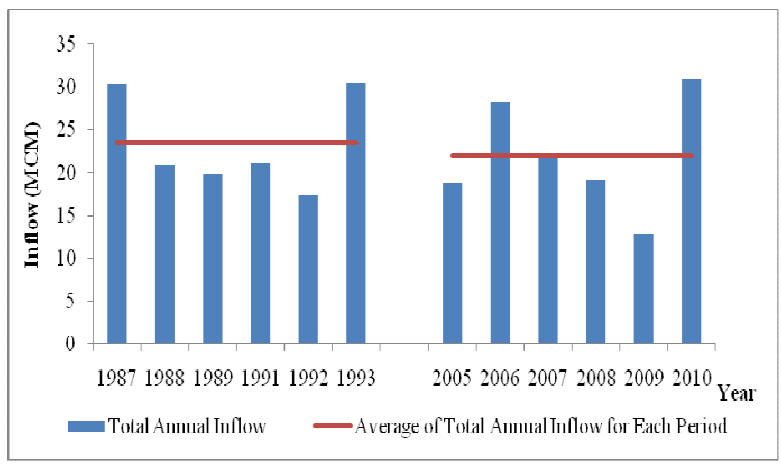

Fig. 8. The total annual inflow to the reservoir from 1987-1993 and 2005-2010 
Table 3 presents the average minimum, maximum and total annual inflow to the reservoir during 1987-1993 and 2005-2010 periods. Inflow to the reservoir has changed over the time with the reduction of minimum flow by $22.22 \%$, maximum flow by $18.57 \%$ and total annual flow by $5.75 \%$ during the two time periods. Consequently, there is a $1.34 \mathrm{MCM}$ average annual inflow reduction in $2005-2010$ period compared to 1987 1993 period. However, the two sample T test results revealed that there is no statistically significant difference in monthly inflow at $95 \%$ confidence level for any month as shown in Table 4.

Table 3. Average minimum, maximum and total annual inflow to the reservoir during 1987-1993 and 2005-2010

\begin{tabular}{lccc}
\hline & \multicolumn{3}{c}{ Inflow (Million $\left.\mathbf{~ m}^{\mathbf{3}}\right)$} \\
\hline Period & Minimum & Maximum & Total Annual \\
& Monthly & Monthly & 23.36 \\
$1987-1993$ & 0.09 & 10.28 & 22.02 \\
\hline
\end{tabular}

Table 4. Reservoir inflow difference between 1987-1993 and 2005-2010

\begin{tabular}{lcc}
\hline Month & $\begin{array}{c}\text { Inflow Difference between 1987- } \\
\mathbf{1 9 9 3} \text { and 2005-2010 periods }\end{array}$ & $\begin{array}{c}\boldsymbol{p} \text { value obtained } \\
\text { from the analysis* }\end{array}$ \\
\hline January & -0.655 & 0.573 \\
February & 0.082 & 0.836 \\
March & -1.931 & 0.118 \\
April & 0.877 & 0.680 \\
May & 0.442 & 0.215 \\
June & 0.250 & 0.442 \\
July & 0.088 & 0.721 \\
August & -0.044 & 0.608 \\
September & 0.112 & 0.507 \\
October & 1.394 & 0.528 \\
November & 0.562 & 0.805 \\
December & 0.164 & 0.952 \\
\hline
\end{tabular}

*minimum $p$ value for $95 \%$ confident level is 0.05

Though the changes in inflow are not statistically significant during the two time periods, even a small reduction of inflow in critical months can have a great impact on cultivation in the command area because filling of reservoir at the correct time is important to issue water to the irrigation system. The estimated average runoff coefficient (0.23) for 1987 to 1993 period was slightly higher than the average runoff coefficient $(0.19)$ for 2005 to 2010 showing relatively less surface runoff generation in the latter period. This reduction could be explained with the land use/cover changes in the watershed with time. The actual evapotranspiration in natural vegetation in Hakwatuna Oya is relatively less when compared to the actual evapotranspiration after conversion of perennials to annual crops. During the prolonged dry period experienced in the study site, the actual evapotranspiration is much less than the potential 
evapotranspiration due to soil moisture stress. When agricultural crop is irrigated abstracting groundwater, actual evapotranspiration occurs at the potential rate since there is no limitation of soil moisture. As a result, the total actual evapotranspiration during a year under irrigated agriculture could be higher than the actual evapotranspiration under normal climatic conditions in the dry zone where a substantial number of dry days without rainfall are present. The proliferation of agro wells and the abstraction of ground water which is made available for evapotranspiration may have reduced the total available water within the watershed. This could partly explain the low runoff coefficient during the second period. Farmers also perceive that there are changes in reservoir water availability due to the changes in watershed area (mainly the large scale groundwater abstraction). The limitation of this analysis is that it was carried out using estimated reservoir inflow values. There were no any measured inflow values to compare with the estimates.

\section{Variations of reservoir inflow with land cover dynamics and groundwater abstraction}

The land use/cover change assessment in this study identified a considerable forest cover reduction and increment of agricultural and plantation areas in the watershed during 1986 to 2014 time period. Proliferation of agro wells in this area is a result of the expanding agricultural activities. Before 1994, only a few number of agro wells were present and it has increased by $80 \%$ from 1994 to 2013 period indicating a large scale groundwater abstraction for agriculture.

The correlation analysis between groundwater abstraction and reservoir inflow clearly show that there is a negative correlation between average monthly groundwater abstraction in the watershed and average monthly inflow to the reservoir. The correlation coefficient is $-0.682(p>0.014)$ for the 1987-1993 period and it is $-0.770(p>0.003)$ for 2005-2010 period. According to the regression analysis, average monthly groundwater abstraction can explain $46.6 \%(p>0.014)$ of the variation of reservoir inflow during $1987-1993$ and it is $59.3 \%$ ( $p>0.003$ ) for $2005-2010$ period. This is an indication to show the influence of groundwater abstraction on inflow to the Hakwatuna Oya reservoir over the time. Hence, expansion of large scale groundwater abstraction in the watershed area can have a negative impact on the reservoir water yield with time.

\section{Groundwater abstraction and implications on reservoir water balance}

Though it is not directly evident from the available limited data, abstraction of groundwater may have an impact on the water availability in Hakwatuna Oya reservoir. Before the settlements begin and agriculture came into practice in the watershed area, it can be assumed that the contribution of rainfall is high for the reservoir inflow. At present, there are around 2662 farmers live in the watershed. Therefore, in order to estimate the total groundwater abstraction from the watershed, the estimated agro-well diffusion value of 71 for 100 farmers was used. Accordingly, the estimated total number of agro-wells in the watershed was 1890. Since the average annual abstraction of groundwater from one well is $7606 \mathrm{~m}^{3}$, the estimated total annual abstraction from this area was $14.38 \mathrm{MCM}$. 
Fig. 9 illustrates the variation of average monthly groundwater abstraction; average monthly reservoir inflow variation and potential inflow to the reservoir for 1987-2010 if there is no any groundwater abstraction in Hakwatuna Oya watershed (assuming that the total amount of abstracted groundwater will contribute to the reservoir).

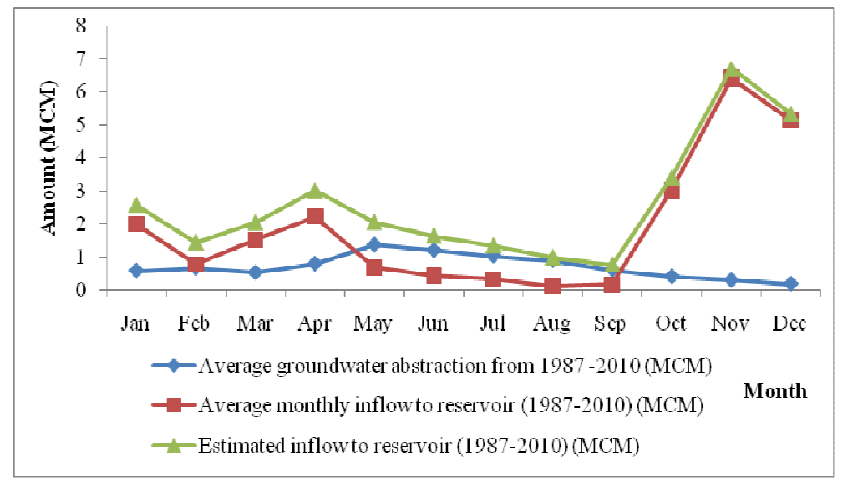

Fig. 9. Variation of average monthly groundwater abstraction, average monthly reservoir inflow and potential monthly reservoir inflow for 1987 to 2010

According to the results, there is a potential threat to the reservoir storage as a result of groundwater abstraction in agricultural lands in the watershed. Hence, it is important to have a good balance between other land uses which can facilitate groundwater recharge. Field observations revealed that the streams get completely dry during non rainy periods (no base flow). As there is no considerable groundwater contribution to the stream flow and abstraction of stream water by the upstream farmers, less or no inflow is received by the reservoir during dry periods. Considering these facts, it is important to assess the long term variation of reservoir capacity during wet and dry periods to identify any possible impact from heavy groundwater abstraction in the watershed area. Since the farming community in the command area is totally depend on reservoir water for their livelihood, proper control of watershed activities is important to protect the Hakwatuna Oya reservoir and the irrigation system.

\section{CONCLUSIONS}

Forest, home gardens and agricultural lands in Hakwatuna Oya watershed have undergone significant changes during the period of 1986 to 2014. However, the rate of change is not uniform throughout the period. According to the study, 1986 to 1994 period is the most critical since majority of changes have occurred during this period. A proliferation of agro-well irrigation was observed as a result of village settlement programmes and the forest cover encroachment for agriculture. Agro well diffusion and agro well density exceed the recommended values. No statistically significant difference in monthly inflow to the reservoir was identified during 1987-1993 and 2005-2010 periods. However, a small change in water availability can make a big impact on the agricultural activities in the command area. There is a potential impact on the reservoir storage due to groundwater abstraction in the watershed. It is understood that the on- 
going changes in the watershed area can bring adverse impacts on the reservoir water yield and subsequently on the irrigation system fed by the reservoir.

\section{ACKNOWLEDGMENT}

This work was carried out with the aid of a grant from the International Development Research Centre, Ottawa, Canada. Their financial support is greatly acknowledged.

\section{REFERENCES}

Abesinghe, K.G.A.M.C.S., Nandalal, K.D.W. and Piyasiri S. (2005). Prediction of Thermal Stratification of the Kotmale Reservoir Using A Hydrometric Model, J.Natl.Sci.Found., 33(1), 25 - 36.

Biemans, H., Haddeland, I., Kabat, P., Ludwig, F. Hutjes, R.W.A., Heinke, J., von Bloh,W., and Gerten, D.(2011). Impact of reservoirs on river discharge and irrigation water supply during the 20th century, Water Resources Research, 47, W03509, doi: 10.1029/2009WR008929Department of Irrigation Kurunegala Reports, (1999).

Gaiser, T., Krol, M.S., Frischkorn, H. \&Araújo, J.C. de (eds) (2003). Global Change and Regional Impacts: Water Availability and Vulnerability of Ecosystems and Society in the Semi-arid Northeast of Brazil, Springer-Verlag, Berlin, Germany.

Güntner, A., Krol, M.S., De Araújo, J.C. and Bronstert, A. (2004). Simple water balance modelling of surface reservoir systems in a large data-scarce semiarid region, Hydrological Sciences Journal, 49(5), 901-918.

International Commission of Large Dams (ICOLD) (2007). World Register of Dams, Int.Comm, Large Dams, Paris, France.

Soil map of Polpitigama DS Division, Research of Land use planning office, Kurunegala, Sri Lanka.

Nie, W., Yuan, Y., Kepner, W., Nash, M.S., Jackson, M. and Erickson,C.(2011). Assessing impacts of Land use and Land cover changes on hydrology for the upper San Pedro watershed, Journal of Hydrology, 407(2011), 105 - 114.

Okkan, U. (2012).Wavelet neural network model for reservoir inflow prediction, ScientiaIranica, A (2012) 19(6), 1445 - 1455.

Park, G.A., Ahn, S.R., Lee, Y.J., Shin, H.J., Park, M.J., and Kim, S.J.(2009). Assessment of climate change impact on the inflow and outflow of two agricultural reservoirs in Korea, [Accessed on 19.08.2014] Available at the http://konkuk.ac.kr/ kimsj/2002/ introduction/papers/PGA_2009_001.pdf.

Punyawardana, B.V.R. (2008). Rainfall and Agro-ecological Zones of Sri Lanka, Department of Agriculture, Sri Lanka. 
Rambe and Madahapola Agrarian Service Centers Reports, (2013)

Samaranayake, W.R. (2011). Impact of Land Use Changes on Watersheds in Dry and Intermediate zones of Sri Lanka (Case Study from Kurunagala District), Sri Lanka.

Smakhtin, V.U. (2001). Low flow hydrology: a review, Journal of Hydrology, 240, 147 186.

Smakhtin,V.U., Shilpakar, R.L. and Hughes, D.A. (2006). Hydrology-based assessment of environmental flows: an example from Nepal. Hydrological Sciences-Journal, 51(2), $207-222$.

Van Oel, P.R., Krol, M.S., Hoekstra, A.Y. and De Araújo, J.C. (2008). The impact of upstream water abstractions on reservoir yield: the case of the Orós Reservoir in Brazil, Hydrological Sciences-Journal-des Sciences Hydrologiques, 53(4).

Wang, J., Ishidaira, H., and, Xu, Z.X.(2012). Effects of climate change and human activities on inflow into the Hoabinh Reservoir in the Red River basin, Procedia Environmental Sciences, 13(2012), 1688 - 1698.

Wijesekera, N.T.S., Karunaratna, K.N.C., and Nishantha, K.G.K.R. (2001). A Comparison of Storage Enhancement Practices-Case Study of Two Reservoirs in Kurunegala District of Sri Lanka, Journal of the institute of engineers Sri Lanka, Vol: xxxiv. 03, $52-57$.

World Commissionon Dams (WCD) (2000). Dams and development: A new framework for decision-making, Earthscan, London. 